KIIz Dergısı $3(1-2) \quad 68-69$

\title{
PSIKOSOSYAL VE MEDIKAL YÖNLERIYLE KAYIP, YAS, ÖLÜM
}

\author{
OğuzE BERKSUN*
}

Her ınsan kaçınıımaz olarak, yaşamı boyunca başetmesı gereken sayısız olayla ve sorunla karşılaşır ve bu sorunların çoğunun ustesınden gelır Ancak bu olayların bır kısmı, yaşamı, belırgın bır biçımde etkıler Sevılen bır yakının, ozellıkle beklenmedık ólumu bu tıp olaylardandır Yaşamı çoğunIukla kesıntıye uğratır ve doğurduğu yalnızlık, ekonomık sorunlar, bakım eksıklı̆ı, guvensızlık gıbı ek stres kaynakları lle bırlıkte bıreyı, bıyopsıkososyal alanlarda çeşıtı ıısklerle karşı karşıya bırakır Yapılan araştırmalar, yaşam olayları sonrası ruhsal ve bedensel hastalıkların ınsıdansında bır artıs olduğunu gostermektedır Gunumuzde, sevilen bır yakının olumu nedenıyle ortaya çıkan, normal bır reaksıyon olarak deǧerlendirilen yas reaksıyonu ustune pek çok yayın yapılmışı ır Yas bır yakının ólumu lle ortaya çıkan duygusal, bılışsel, davranışsal, bedensel ve sosyal alanda değışımlerle belırlenen karmaşık bır yaşantı, ınsan ıçı kaçınıımaz ve evrensel bir deneyımdir Bir yaniyla adaptıf ve ıyleşmeye hızmet eden ve bu nedenle bazı psıkoterapı turlerınde kullanılan dığer yanıyla Parkes'ın sóyledığı gıbı, enflamasyon reaksıyonlarına benze. yen ve çeşıth olumsuz gelışmelerı ıçınde barındıran ıkılı bır sureçtır

Lindemann yası belırlı, semptomatolojısı ve gıdışı olan bır sendrom olarak ele almıştır Ona gore, akut yas, ılk bakışta bır rahatsızlık oimasa da doğurabıleceğı sonuçlar açısından onemsenmesı ve ele alınması gereken bir durumdur Bedensel ruh-

- Uzm Dr A U Psıkıyatrık Krız Uyg Arş Mrkz sal pek çok belirt lle seyredebilır, bır krizle ortaya çıkabııı, gecıkebılır, abartılabılır, çarpıtılabılır veya hıç ortaya çıkmayabılır Boyı́ normal dışı seyır gósteren tablolar mudahaleyı gerekturi ve uygun teknıklerle normal yas reaksıyonlarına çevrilebılır Macnab, yas reaksiyonu gosteren bireylerın acıl Jlarak duygusal bır rehabilitasyon surecine intyyaç gósterdiklerını belırtır Macnab'a gore bu surecın ónunde uç engel vardır flkı, bır yanıisama olarak. blenle ılşkıyı surdurmeye yarayan nevrotık duygusal acı çekme ısteğı, ıkıncısı, dığer ınsanların, gerıde kalanların sankı duygusal bır acı ıçındeymış gıbı davranmalarına olan zorlayıcı beklentısı, uçuncusu ıse yas ıçındekı ınsanların duygusal rehabılıtasyonu bir amaç olarak gormemelerıdır Bu rehabılıtasyon surecının ónundekı engellerte birlikte bireyın bulun. duğu gelışımsel aşarna, daha óncekı kayıplaria ılgıiı yaşantılar ve bu kayıplarla başa çıkma bıçımı, ólen. le ilışkılerın boyutu ve nttelığı, ozelıkle olene karşı bılınç duzeyınde veya bilınç dişı ambıvalansın veya duşmanlığın oluşu, ışlevsel olan guncel sosyal destek sıstemı, kışının olume hazırlıklı olup oimadığı, kayıpla ortaya çıkan ekonomık zorlukiarın boyutu, rıtueller aracılığıyla yas surecını kolaylaştıran sosyokulturel yapı, kaybın ağırlığı ıle bırlıkte ıçerdı̆̆ı anlamlar ve doğurduğu sonuçlar yasın gıdışını belirleyen onemlı faktorlerdendır Çeşıtłı yazarlara gore terminolos biraz farkis olsa da genel olarak yas reaksıyoniarı tıpık yas ve patolojık (ya da komplıkasyonlu) yas olmak uzere ıkı başlık halınde incelenır Bibring ve Jacobson, Freud'un goruşlerı lie uyumlu olarak (1917) patoiojlk yas reaksıyonları nın ortaya çıkmasında terkedılmışıı yaşantısının rol oynadığı, kaybedılene duyulan ofkenın açığa 
vurulamaması, bastırılması ve ozbenliğe yöneltilmesinin önemine değinirler. Yas dönemindeki bir kişide ruhsal ve bedensel belirtiler ile birlikte bir depresif tablo söz konusudur. Ancak degersizlik duygularının aşırı düzeye çıkması, iş yapma yeteneğinin uzun süreli ve ağır derecede azalması ve belirgin psikomotor yavaşlama, intihar düșünceleri alışılagelmişin dışında belirtilerdir ve yasın major depresyon yönüne kaydığını gösterir. Yas tutan kişi kendi depresif duygulanımını normal bulur, ancak uykusuzluk, iştah kaybı deli olma korkusu ve bazı bedensel belirtiler nedeni ile hekime başvurabilir.

Burada Psikiyatrik Kriz Uygulama ve Araştırma Merkezine yapılan başvurulardan da kısaca bahsetmek istiyorum. Merkezimize, sevilen bir yakının kaybı sonrası çeşitli yakınmalarla başvuran kişilerin sayısı tüm başvuruların \%10'unu oluşturmaktadir. Deneyimlerimiz, 1-hastaların, merkeze durumdan endişe duyan yakınlarının onerisi ve isteği dogrultusunda, 2-genellikle olümden bir veya birkaç hafta geçtikten ve şok dönemi atlatıldıktan sonra geldikleri ya da getirildiklerini, 3- ilk birkaç saat ya da gūn içindeki, konversiyon, dissosiasyon, kısà reaktif psikoz, kendini yaralama gibi nedenlerle yaptlan başvuruların neredeyse tümünün doğrudan acil servislere yapıldığını, 4-merkeze yapulan başvurularda onde gelen nedenterin yogun sıkıntı, depresif belirtiler, günlük işlerini sürdürmede zorlanma, isteksizlik, intihar düşünceleri veya girişimleri, unutkanlik, konsantrasyon gūçlügü, uykusuzluk ve somatik yakınmalar olduğunu, 5olümü takip eden birkaç aydan sonraki başvuru nedenlerinin ise daha çok sosyal desteğin azalışının hissedildiği dönemde, örneğin, yalntzłık duygusu, dul kalma, sorumlulukların artması, ekonomik problemler, güvensizlik, başka ayrılık tehditleri ve ne yapacağını bilememe ve uyum güçlükleri gibi ölümü izleyen sorunların yarattığı anksjyeteden kaynaklandığını gőstermektedir.

Aslında nomal işleyen bir yas süreci herhangi bir müdahaleyi gerektirmez ancak hiçbir yas sürecinin de bu kadar normal olduğunu sőylemek yada olacağını kestirmek mümkün değildir. lç göçün, kültürrel ve ekonomik yapıda ortaya çıkan değişim. lerin etkisiyle alışıldık toplumsal orüntünün, işleyişin, desteklerin, geleneklere bağılığın bozuluşu da dikkate alındığında yas süreci için koruyucu ruh sağlığı hizmetleri açısından belirli anlayışları benimsemek ve yerleştirmek belki de yerinde olacaktır. Bu amaçla dört temel aforizmadan sőzedilebilir.

1- Ne kadar insani, kaçınılmaz ve normal bir süreç olsa da komplikasyonlara gebe oluşu nedeniyle her yas süreci aslında açık bir yaranın iyileşme sürecinde hak ettiği ozeni gerektirir.

2. Normal yas sürecinin kendisi aslında doğal rehabilitatif bir süreçtir. lyi işleyen bir yas süreci kayıpla birlikte açılan ağır duygusal bir yaranın ve sekellerin iyileşmesini sağladığı gibi önceden var olan yaralarında iyileşmesine yardımcı olabilir.

3- Komplikasyona ugrayan yas süreci ise organizmanın kendi kendisine zarar verdiği bir otoimmün bir süreç olarak düşünülebilir.

\section{YAS SÜRECI VE YAPILABILECEK YARDIM- LAR}

1. Macnab'ın sözettiğ bir yanılsama olarak, ठlenle jlişkiyi sürdürmeye yarayan nevrotik duygusal acı çekme isteğini, diğer insanların, geride katanların sanki duygusal bir acı içindeymiş gibi davranmalarına olan zorlayıcı beklentisi, yas içindeki insanlarin duygusal rehabilitasyonu bir amaç ola. rak görmemeleri engellerini ortadan kaldırmak. Duygusal veya fonksiyonel rehabilitasyonu sağlamak veya işleyen doğal rehabilitasyon sürecinin yolunda gitmesine katkıda bulunmak ve hızlandırmak.

2- Kriz durumlarında normal sürecin ônündeki engelleri kaldırmaya dönük krize müdahale,

3- Çocuk ölümlerinde olduğu gibi boşanmaya kadar gidebilecek saklı potansiyel krizlerin veya eşlik eden krizlerin saptanması ve çözülmesine đơnük krize müdahale,

4- Patolojik yas veya komplike yas durumlarında psikiyatrik tedaviler, uzun dönemli psikoterapiler şeklinde sıralanabilir. 